\title{
DURABILITY OF EUCALYPTS WOOD IN SOIL BED AND FIELD DECAY TESTS
}

\author{
Pedro Nicó de Medeiros Neto ${ }^{1, \star}$, Juarez Benigno Paes ${ }^{2}$,José Tarcísio da Silva Oliveira ${ }^{2}$, \\ João Gabriel Missia da Silva ${ }^{2}$, José Clailson Franco Coelho ${ }^{3}$, Libânia da Silva Ribeiro ${ }^{4}$
}

\begin{abstract}
This evaluated the natural resistance of wood from seven Eucalyptus trees in field decay and soil bed tests. Two 12-year-old trees were randomly sampled per species, with 2,2 $\mathrm{m}$ logs being obtained from the basal section of each tree. The samples were taken in two positions in the radial direction of the stem (middle heartwood and transition zone; containing heartwood and sapwood). The field decay tests were installed in three municipalities in the southern state of Espírito Santo, and the soil utilized soil from the three field decay test areas. The field decay tests were evaluated after six, 12 and 18 months after installation and the soil bed tests after six months. The Scott-Knott test $(\mathrm{p} \leq 0,05)$ was used in the analysis and evaluation of the tests. The sapwood-heartwood (transition region) exhibited the greatest mass losses for the field decay and soil bed tests. On average, for the soil bed test the lowest mass losses were observed for the soil of Vargem Alta $(5,00$ \%), with greater mass losses observed for São José do Calçado (7,05 \%) and Jerônimo Monteiro (9,90 \%). In the field decay test the organisms present in the soil of São José do Calçado and related to the organic matter content Eucalyptus grandis and Eucalyptus saligna more intensely.
\end{abstract}

Keywords: Biodeterioration, edaphoclimatic characteristics, natural resistance, pith-bark direction.

\section{INTRODUCTION}

Woody resources have been used to produce energy, pulp and paper, and construction material for urban and rural environments, the furniture industry and medicinal products. Wood stands out because of its importance as a renewable and more accessible product than sources of raw materials such as fossil fuels and other building materials. Nevertheless, as it is a material of organic origin, it is subject deterioration. However, there are also species that produce wood resistant to attack by xylophagous organisms, which were widely used in different works, leading to their scarcity.

The lack of native species that high resistance to biological deterioration stimulated the search for other species which could supply the demand. Thus, reforestation with Eucalyptus and Pinus began. Few studies are related to the natural durability of eucalypts wood in Brazil (Silva et al. 2004, Morais and Costa 2007, Paes et al. 2015). The use of naturally durable woods has an advantage compared to chemically treated wood, since there are no problems after their use (Sundararaj et al. 2015). According to the Brazilian Tree Industry (IBÁ 2019), the Eucalyptus plantations in Brazil correspond to 5,7 million hectares, therefore necessitating research for its best use.

Laboratory and field tests can be performed in evaluating the natural resistance of wood and derivatives to the xylophagous agents. Laboratory tests provide faster information, but the field provides that are more realistic because wood is exposed to insects, fungi and edaphoclimatic conditions (Ali et al. 2011, Meyer et al. 2014, Araújo and Paes 2018). Thus, wood is exposed to a range of physical, chemical and biological agents of

${ }^{1}$ Federal University of Campina Grande, Patos, PB, Brazil.

${ }^{2}$ Federal University of Espírito Santo, Jerônimo Monteiro, ES, Brazil.

${ }^{3}$ Federal University of Acre, Cruzeiro do Sul, AC, Brazil.

${ }^{4}$ Federal University of Campina Grande, Campina Grande, PB, Brazil.

•Corresponding author: pedroflorestal@gmail.com

Received: 06.08.2019 Accepted: 23.05.2020 
the environment and soil in field evaluations. This often poses high risks of biodeterioration by allowing the wood to have contact with a variety of agents such as soil, insects or inoculation with microorganisms (Paes et al. 2007, Paes et al. 2009, Brischke et al. 2013a).

Although wood in field tests remains exposed to the edaphoclimatic and biological conditions that could occur during their daily use, they require a longer period of time for their evaluation resulting in increased costs (Susi et al. 2011, Paes et al. 2012). An alternative,soil bed tests, provide results which are more similar to the actual conditions of use when compared to traditional laboratory tests, and provide an increase in time saving and cost reduction of the research, with the use of smaller samples compared to field trials (Paes et al. 2009, Paes et al. 2012).

Studies in recent years have been focused on finding environmentally correct products and hardwoods that are more resistant to attack by xylophagous agents and faster and more reliable responses, because insufficient natural resistance limits the use of wood. Thus, the objective of this study was to evaluate the natural resistance of seven Eucalyptus wood species in soil bed and field decay tests.

\section{MATERIALS AND METHODS}

\section{Studied species and wood sampling}

In this study, the natural resistance in soil bed and field decay tests of seven Myrtaceae family (Eucalyptus) species (Eucalyptus camaldulensis, E. grandis, E. urophylla, E. robusta, E. saligna, E. pellita and Corymbia citriodora) were evaluated. For this, two 12-year-old trees of seminiferous origin with good phytosanitary health were randomly sampled by species, representing the average diameter of each species in the forest plantation of the CENIBRA SA company, municipality of Guanhães, Minas Gerais State, Brazil (Latitude $18^{\circ} 46^{\prime} 16^{\prime \prime}$ South, Longitude $42^{\circ} 55^{\prime} 55^{\prime \prime}$ West and 744 meters altitude).

Logs of 2,2 $\mathrm{m}$ were obtained from the basal section of each tree for the tests, and samples were taken from two positions in the radial direction of the trunk (middle heartwood and transition region of heartwood and sapwood, containing heartwood and sapwood) due to the length of the diameter of the studied woods.

\section{Soil bed test}

The recommendations of Vinden et al. (1982), Paes et al. (2002), Paes et al. (2009) and the American wood Protection Association Standard E14-14 (AWPA 2014) were followed. The simulators were assembled in lined boxes, measuring $60 \mathrm{~cm} \times 60 \mathrm{~cm} \times 50 \mathrm{~cm}$. Each box was filled with the soil of a locality where the field decay test was installed and maintained at $25{ }^{\circ} \mathrm{C} \pm 2{ }^{\circ} \mathrm{C}$ and $65 \% \pm 5 \%$ relative humidity (Figure 1). Soils were broken down into two horizons: Horizon $\mathrm{a}=0-10 \mathrm{~cm}$ deep; Horizon $\mathrm{b}=10-20 \mathrm{~cm}$ deep. The soil profile in the boxes were as follows: $15 \mathrm{~cm}$ of gravel followed by $25 \mathrm{~cm}$ from Horizon b and topped with 10 $\mathrm{cm}$ from Horizon a.

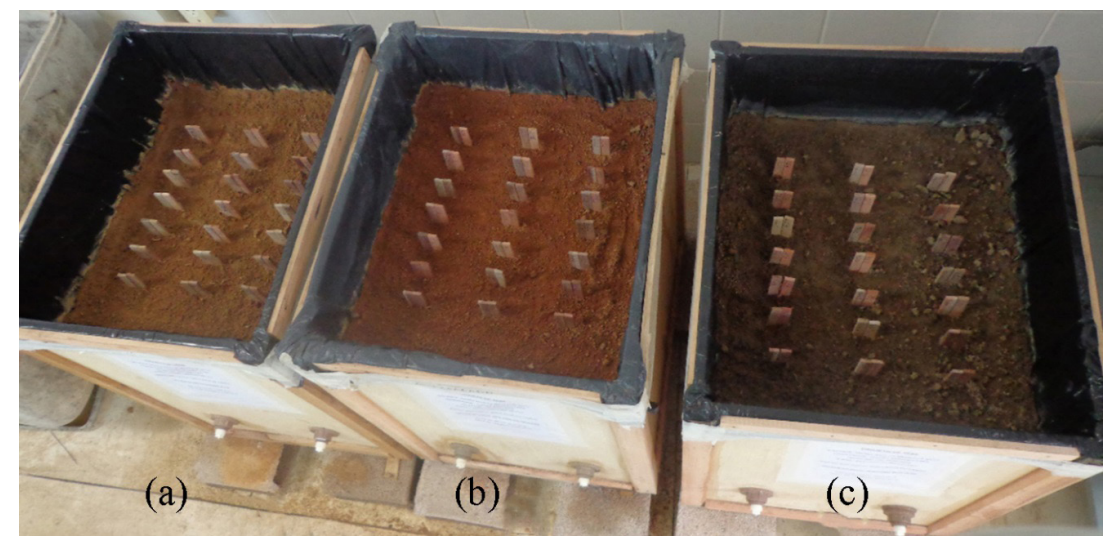

Figure 1: Soil bed test with the seven eucalypts wood and soils of the municipality evaluated: (a) Vargem alta; (b) São José do Calçado; (c) Jerônimo Monteiro, Espírito Santo State, Brazil. 
Samples of $15 \mathrm{~cm}$ x $1,5 \mathrm{~cm} \times 0,5 \mathrm{~cm}$ (length $\mathrm{x}$ width $\mathrm{x}$ thickness) were used in this experiment. The samples were dried in an oven at $103{ }^{\circ} \mathrm{C} \pm 2{ }^{\circ} \mathrm{C}$ until reaching constant mass. These were partially buried $(2 / 3$ of the length) and randomly distributed in the soil bed according to a randomized block design. The soil beds moisture contents were maintained close to the soil water holding capacity. Four ports in the boxes were used for drainage.

Samples were analyzed after 180 days of installation by visual analysis and by the assignment of grades used for the field test (Table 1). Mass loss was determined after conditioning $103{ }^{\circ} \mathrm{C} \pm 2{ }^{\circ} \mathrm{C}$ until reaching constant mass.

Table 1: Criteria for assessment of the stakes in the decay field test.

\begin{tabular}{|c|c|c|}
\hline Decay level & Rating system & Index of Condition \\
\hline No attack (sound) & 0 & 100 \\
\hline Surface attack & 1 & 90 \\
\hline Moderate attack & 2 & 70 \\
\hline Severe attack & 3 & 40 \\
\hline Breaking & 4 & 0 \\
\hline
\end{tabular}

Source: Becker (1972).

\section{Field decay test}

For simplicity, small wood stakes and short exposure times were used (Becker 1972). The method used specimens measuring $50,0 \mathrm{~cm} \times 5,0 \mathrm{~cm} \times 2,5 \mathrm{~cm}$ (length $\mathrm{x}$ width $\mathrm{x}$ thickness) containing the middle heartwood or transition region of the heartwood and sapwood. The samples were held for four months at $25^{\circ} \mathrm{C} \pm 2{ }^{\circ} \mathrm{C}$ and $65 \% \pm 5 \%$ relative humidity.

The tests were installed in the municipalities of Jerônimo Monteiro (JM) (Latitude 2047'22" South, Longitude $41^{\circ} 23^{\prime} 42^{\prime \prime}$ West and 110 meters altitude), São José do Calçado (SJC) (Latitude $21^{\circ} 1^{\prime} 31^{\prime}$ " South, Longitude 41 $39^{\prime} 20^{\prime \prime}$ 'West and 316 meters altitude), and Vargem Alta (VA) (Latitude 2040'17' South, Longitude $41^{\circ} 00^{\prime} 25^{\prime \prime}$ West and 650 meters altitude), Espírito Santo State, Brazil (Figure 2). Samples were inspected after 6,12 , and 18 months exposure. In this way, it was possible to evaluate the decay index in the wood for in periods and locations with different edaphoclimatic characteristics. Samples were taken from Horizons A and B at the installation sites in each municipality and analyzed for the physical and chemical characteristics of the soils (Table 2) and material for the assembly of the soil beds.

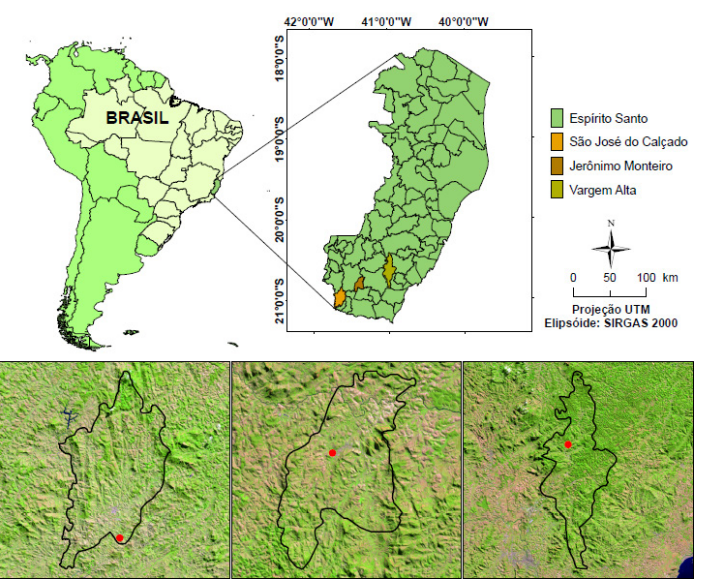

Figure 2: Location of the municipalities where the decay field tests were installed with the seven eucalypts wood. 
Table 2: Physical and chemical characteristics of the soils in the municipalities of Jerônimo Monteiro, São José do Calçado and Vargem Alta, Espírito Santo, Brazil ${ }^{1}$.

\begin{tabular}{|c|c|c|c|c|c|c|c|c|c|c|c|}
\hline \multirow[t]{2}{*}{ Local } & \multirow{2}{*}{$\begin{array}{c}\begin{array}{c}\text { Soil } \\
\text { profile }\end{array} \\
\begin{array}{c}\text { Depth } \\
(\mathrm{cm})\end{array}\end{array}$} & \multirow{2}{*}{$\begin{array}{c}\mathrm{pH} \\
\left(\mathrm{H}_{2} \mathbf{O}\right)\end{array}$} & $\mathbf{K}^{+}$ & $\mathbf{P}^{+}$ & $\mathrm{Ca}^{+2}$ & $\mathrm{Mg}^{+2}$ & $\mathbf{H}^{+}+\mathbf{A l}^{+3}$ & CEC & $\mathrm{C}$ & OM & \multirow{2}{*}{$\begin{array}{c}\text { BS } \\
\%\end{array}$} \\
\hline & & & \multicolumn{2}{|c|}{$\mathrm{mg} \cdot \mathrm{dm}^{-3}$} & \multicolumn{4}{|c|}{$\mathrm{cmol} \cdot \mathrm{dm}^{-3}$} & \multicolumn{2}{|c|}{$\mathrm{g} \cdot \mathrm{kg}^{-1}$} & \\
\hline \multirow{2}{*}{$\begin{array}{l}\text { JM } \\
\text { soil }\end{array}$} & $\mathrm{A}(0-10)$ & 7,8 & 82,0 & 14,0 & 4,20 & 0,9 & 0,3 & 5,61 & 10,8 & 18,6 & 94,7 \\
\hline & $\mathrm{B}(10-20)$ & 6,2 & 32,0 & 2,0 & 1,40 & 0,5 & 1,7 & 1,98 & 2,1 & 3,60 & 53,8 \\
\hline \multirow{2}{*}{$\begin{array}{l}\text { SJC } \\
\text { soil }\end{array}$} & $\mathrm{A}(0-10)$ & 5,7 & 142,0 & 5,0 & 1,90 & 0,9 & 4,5 & 3,26 & 10,2 & 17,6 & 41,3 \\
\hline & $\mathrm{B}(10-20)$ & 4,9 & 60,0 & 1,0 & 0,90 & 0,4 & 5,3 & 1,75 & 5,1 & 8,8 & 21,5 \\
\hline \multirow{2}{*}{$\begin{array}{l}\text { VA } \\
\text { soil }\end{array}$} & A & 5,7 & 88,0 & 1,0 & 0,70 & 0,4 & 3,0 & 1,33 & 5,0 & 8,6 & 30,7 \\
\hline & $\mathrm{B}(10-20)$ & 5,4 & 43,0 & 1,0 & 0,60 & 0,2 & 4,0 & 1,41 & 2,3 & 4,0 & 18,5 \\
\hline
\end{tabular}

CEC: effective cation exchange capacity; OM: organic matter; BS: Percent base saturation.

Three replications for each position and from each tree were installed per location. The recommendations of Becker (1972) in Table 1 were used in the evaluation of the attack intensity by deteriorating agents.

\section{Analysis and evaluation of the results}

A randomized complete block design was used to compare the natural resistance of the woods in the soil bed and field decay tests, with a split plot scheme with three replicates (block), with the plots (species) and subplots (pith-bark position).

When necessary, the deterioration condition data (rating) were transformed into $\sqrt{\text { rating }+0,5}$ and the mass loss data into $\arcsin \sqrt{\left(\frac{\text { mass loss }}{100}\right)}$ to enable statistical analyses. These transformations, suggested by Steel and Torrie (1980), were used to normalize the distribution of the data (Lilliefors test) and to homogenize the variances (Cochran and Bartlett test). The Scott-Knott test $(p \leq 0,05)$ was used in the analysis and evaluation of the tests for the factors and interactions detected as significant by the F-test $(\mathrm{p} \leq 0,05)$.

\section{RESULTS AND DISCUSSION}

\section{Soil bed tests}

The soil bed test filled with soil from the municipality of Jerônimo Monteiro did not show a significant interaction for the mass loss between the positions and the eucalypts wood evaluated. The mass losses between the eucalypts wood were statistically the same (Table 3 ). The wood from the middle heartwood showed less mass loss when compared to that from the transition region.

Table 3: Average values of mass loss and decay index (DI) of the species and positions evaluated in soil bed test, for soils from Jerônimo Monteiro, São José do Calçado and Vargem Alta, Espírito Santo municipalities, Brazil.

\begin{tabular}{|c|c|c|c|c|c|c|c|c|c|c|}
\hline \multirow[t]{2}{*}{ Place } & \multirow[t]{2}{*}{ Variables } & \multicolumn{7}{|c|}{ Species } & \multicolumn{2}{|c|}{ Positions } \\
\hline & & Es & Eg & $\mathrm{Eu}$ & Ep & $\mathrm{Ec}$ & $\mathrm{Cc}$ & Er & $\mathrm{Hw}$ & Tw \\
\hline \multirow[t]{2}{*}{ JM } & Mass loss & $9,37 \mathrm{~A}$ & $13,32 \mathrm{~A}$ & $8,93 \mathrm{~A}$ & $9,66 \mathrm{~A}$ & $9,98 \mathrm{~A}$ & $10,69 \mathrm{~A}$ & $7,34 \mathrm{~A}$ & $7,90 \mathrm{~B}$ & $11,90 \mathrm{~A}$ \\
\hline & $\begin{array}{l}\text { Decay } \\
\text { index }\end{array}$ & $0,83 \mathrm{~A}$ & $1,00 \mathrm{~A}$ & $0,00 \mathrm{~B}$ & $0,00 \mathrm{~B}$ & $0,00 \mathrm{~B}$ & $0,00 \mathrm{~B}$ & $0,00 \mathrm{~B}$ & $0,33 \mathrm{~A}$ & $0,19 \mathrm{~A}$ \\
\hline \multirow[t]{2}{*}{ SJC } & Mass loss & $11,87 \mathrm{~A}$ & $11,91 \mathrm{~A}$ & $4,78 \mathrm{~B}$ & $5,28 \mathrm{~B}$ & $6,42 \mathrm{~B}$ & $4,92 \mathrm{~B}$ & $4,15 \mathrm{~B}$ & $5,99 \mathrm{~B}$ & $8,10 \mathrm{~A}$ \\
\hline & $\begin{array}{l}\text { Decay } \\
\text { index }\end{array}$ & $2,67 \mathrm{~A}$ & $2,00 \mathrm{~A}$ & $0,17 \mathrm{~B}$ & $0,17 \mathrm{~B}$ & $0,00 \mathrm{~B}$ & $0,00 \mathrm{~B}$ & $0,00 \mathrm{~B}$ & $0,71 \mathrm{~A}$ & $0,72 \mathrm{~A}$ \\
\hline \multirow[t]{2}{*}{ VA } & Mass loss & $4,32 \mathrm{~A}$ & $5,39 \mathrm{~A}$ & $4,35 \mathrm{~A}$ & $5,87 \mathrm{~A}$ & $5,66 \mathrm{~A}$ & $6,87 \mathrm{~A}$ & $2,59 \mathrm{~A}$ & $4,23 \mathrm{~B}$ & $5,79 \mathrm{~A}$ \\
\hline & $\begin{array}{l}\text { Decay } \\
\text { index }\end{array}$ & $0,00 \mathrm{C}$ & $1,00 \mathrm{~A}$ & $0,00 \mathrm{C}$ & $0,50 \mathrm{~B}$ & $0,00 \mathrm{C}$ & $0,00 \mathrm{C}$ & $0,00 \mathrm{C}$ & $0,24 \mathrm{~A}$ & $0,19 \mathrm{~A}$ \\
\hline
\end{tabular}

ES: Eucalyptus saligna; Eg: Eucalyptus grandis; Eu: Eucalyptus urophylla; Ep: Eucalyptus pellita; Ec: Eucalyptus camaldulensis; Cc: Corymbia citriodora; Er: Eucalyptus robusta; Hw: Heartwood; Tw: transition wood. Means followed by the same letter across species and positions do not differ at $\mathrm{p}<0,05$ (Scott-Knott test). 
Regarding decay index, the positions were statistically similar, and the E. grandis and E. saligna woods had the highest deterioration (scores). Although this assay is more realistic than the ones in the laboratory, they mainly occur in the presence of soft rot fungi, which cause the wood to deteriorate more slowly than those causing white and brown rot (Shmulsky and Jones 2011). This probably resulted in the similarity of the mass losses among the studied woods.

Regarding the soil of São José do Calçado, there was no significant interaction between the species and the evaluated positions. For the positions tested, the middle heartwood showed the lowest mass losses, while these were statistically similar in relation to the decay index. For the evaluated species, E. grandis and E. saligna exhibited the greatest mass loss and decay index scores, while the other species were statistically the same.

The specimens buried in the soil from the municipality of Vargem Alta showed no significant interaction between the eucalypts wood and the positions tested. When comparing the evaluated positions, the resulting woods from the transition region exhibited the largest mass losses. The mass loss among the eucalypts wood were statistically similar. In relation to the decay index, the tested positions were statistically similar, while when analyzing the species, E. grandis showed the highest deterioration scores, followed by E. pellita, and the other studied woods showed similar values.

In general, the lowest mass losses of were observed for the Vargem Alta soil, except for C. Citriodora and the greatest mass losses were observed for the Jerônimo Monteiro soil, except for E. saligna (Figure 3).

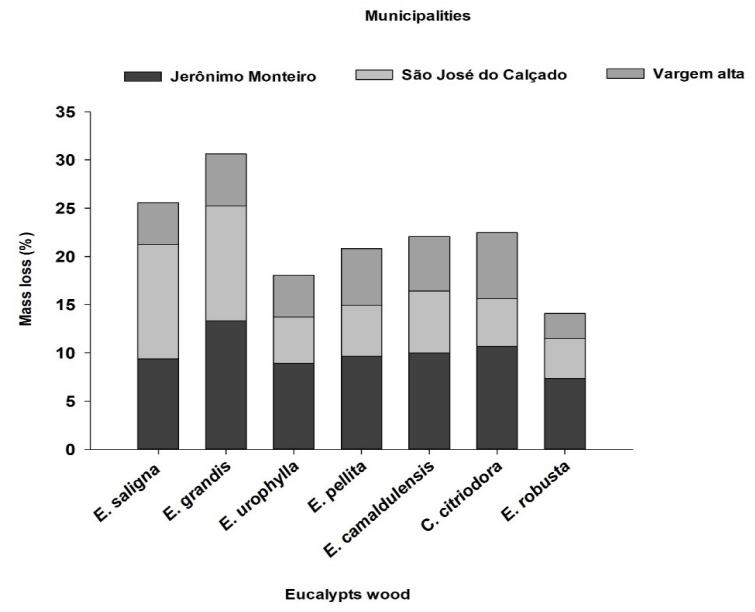

Figure 3: Mass loss of the species and positions evaluated in soil bed test, for soils from Jerônimo Monteiro, São José do Calçado and Vargem Alta, Espírito Santo municipalities, Brazil.

\section{Field decay test}

For the meteorological data of the three municipalities where the field trials were carried out, the highest mean precipitation during the evaluated period was observed for São José do Calçado $(81,55 \mathrm{~mm})$, followed by Vargem Alta $(74,22 \mathrm{~mm})$ and Jerônimo Monteiro $(67,94 \mathrm{~mm})$. For the average temperature, the highest value was for Jerônimo Monteiro $\left(23,28^{\circ} \mathrm{C}\right)$, followed by São José do Calçado $\left(21,78^{\circ} \mathrm{C}\right)$ and Vargem Alta $(19,27$ $\left.{ }^{\circ} \mathrm{C}\right)$. These two climatic factors directly influenced the biodeterioration of wood.

In the field decay test carried out in the municipality of Jerônimo Monteiro, no statistical difference was observed between eucalypts wood and analyzed positions; however, it can be seen that E. saligna, E. grandis and E. camaldulensis had a progressive increase in the deterioration scores during the three evaluations. The transition region exhibited the highest scores when compared to the test specimens obtained from the heartwood samples, but both were statistically the same. For the behavior results, they followed the same trend previously observed for the decay index (Table 4).

This natural similarity was probably created for resist the weathering and attack of xylophagous agents with respect to the evaluation time in the field, which occurred over one year and six months. According to 
Silva and Castro (2014), eucalypts wood has a useful life of between three and four years in the construction of fences, fencepost or stakes without preservative treatment. Thus, the variations in the natural durability among the species studied will be more important in the course of the next months. The same tendency in decay index can be observed for the evaluated eucalypts wood previously exhibited for the soil bed test, which represent a similarity between the two performed tests.

A statistical difference was observed between the two positions evaluated after 12 and 18 months in the municipality of São José do Calçado, in which the transition region exhibited the highest decay index values, being more susceptible to edaphoclimatic and biological factors (Table 4).

Table 4: Decay index (DI) values and behavior of the species evaluated in decay field test in the municipalities of Jerônimo Monteiro, São José do Calçado e Vargem Alta to exposure times and positions in trunks.

\begin{tabular}{|c|c|c|c|c|c|c|c|c|c|c|}
\hline \multirow{2}{*}{$\begin{array}{c}\text { Exposure } \\
\text { time } \\
\text { (months) }\end{array}$} & \multirow[t]{2}{*}{ Variables } & \multicolumn{7}{|c|}{ Species } & \multicolumn{2}{|c|}{ Positions } \\
\hline & & Es & $\mathrm{Eg}$ & $\mathrm{Eu}$ & Ep & Ec & $\mathrm{Cc}$ & $\mathrm{Er}$ & $\mathrm{Hw}$ & Tw \\
\hline \multicolumn{11}{|c|}{ Jerônimo Monteiro } \\
\hline \multirow[t]{4}{*}{6} & DI & $0,33^{1}$ & 0,33 & 0,00 & 0,00 & 0,17 & 0,17 & 0,17 & 0,09 & 0,24 \\
\hline & (rating) & $\mathrm{A}$ & A & $\mathrm{A}$ & A & A & $\mathrm{A}$ & A & A & $\mathrm{A}$ \\
\hline & Behavior & $96,67^{1}$ & 96,67 & 100,00 & 100,00 & 98,33 & 98,33 & 98,33 & 97,62 & 99,05 \\
\hline & index & A & A & A & A & A & A & A & A & A \\
\hline \multirow[t]{4}{*}{12} & DI & 1,33 & 1,50 & 1,00 & 1,00 & 1,17 & 1,50 & 1,50 & 1,19 & 1,38 \\
\hline & (rating) & A & A & A & A & A & A & A & A & A \\
\hline & Behavior & 83,33 & 80,00 & 90,00 & 90,00 & 86,67 & 78,33 & 80,00 & 86,19 & 81,90 \\
\hline & index & A & A & A & $\mathrm{A}$ & $\mathrm{A}$ & A & A & A & A \\
\hline \multirow[t]{4}{*}{18} & DI & 1,50 & 1,67 & 1,00 & 1,00 & 1,33 & 1,50 & 1,50 & 1,28 & 1,43 \\
\hline & (rating) & $\mathrm{A}$ & A & A & A & A & A & A & A & A \\
\hline & Behavior & 80,00 & 76,67 & 90,00 & 90,00 & 83,33 & 78,33 & 80,00 & 84,28 & 80,95 \\
\hline & index & A & $\mathrm{A}$ & $\mathrm{A}$ & $\mathrm{A}$ & $\mathrm{A}$ & $\mathrm{A}$ & A & $\mathrm{A}$ & A \\
\hline \multicolumn{11}{|c|}{ São José do Calçado } \\
\hline \multirow[t]{4}{*}{6} & DI & 1,83 & 2,17 & 1,17 & 0,33 & 1,17 & 0,50 & 2,50 & 1,24 & 1,52 \\
\hline & (rating) & $\mathrm{A}$ & A & $\mathrm{A}$ & A & $\mathrm{A}$ & A & A & A & A \\
\hline & Condition & 73,33 & 51,67 & 81,67 & 96,67 & 80,00 & 93,33 & 55,00 & 78,09 & 73,81 \\
\hline & index & A & A & A & A & A & A & A & A & A \\
\hline \multirow[t]{4}{*}{12} & DI rating) & 2,67 & 3,17 & 2,51 & 1,67 & 2,67 & 1,83 & 3,50 & 2,33 & 2,81 \\
\hline & & $\mathrm{A}$ & $\mathrm{A}$ & A & $\mathrm{A}$ & $\mathrm{A}$ & A & A & A & A \\
\hline & Condition & 50,00 & 30,00 & 51,67 & 75,00 & 50,00 & 71,67 & 20,00 & 56,19 & 43,33 \\
\hline & index & $\mathrm{A}$ & A & A & $\mathrm{A}$ & $\mathrm{A}$ & $\mathrm{A}$ & A & A & A \\
\hline \multirow[t]{4}{*}{18} & DI & 2,67 & 3,33 & 3,00 & 1,67 & 2,67 & 2,33 & 3,50 & 2,47 & 3,00 \\
\hline & (rating) & A & $\mathrm{A}$ & A & A & A & A & A & B & A \\
\hline & Condition & 50,00 & 25,00 & 38,33 & 75,00 & 50,00 & 58,33 & 20,00 & 52,86 & 37,62 \\
\hline & Index & A & $\mathrm{A}$ & $\mathrm{A}$ & $\mathrm{A}$ & $\mathrm{A}$ & $\mathrm{A}$ & $\mathrm{A}$ & $\mathrm{A}$ & B \\
\hline \multicolumn{11}{|c|}{ Vargem Alta } \\
\hline \multirow[t]{2}{*}{6} & $\begin{array}{c}\text { DI } \\
\text { (rating) }\end{array}$ & 0,00 & 0,00 & 0,00 & 0,00 & 0,00 & 0,00 & 0,00 & 0,00 & 0,00 \\
\hline & $\begin{array}{l}\text { Condition } \\
\text { Index }\end{array}$ & 100,00 & 100,00 & 100,00 & 100,00 & 100,00 & 100,00 & 100,00 & 100,00 & 100,00 \\
\hline \multirow[t]{4}{*}{12} & DI & 1,50 & 1,00 & 1,33 & 1,33 & 1,67 & 1,50 & 1,83 & 1,33 & 1,57 \\
\hline & (rating) & A & A & A & A & A & A & A & A & A \\
\hline & Condition & 78,33 & 90,00 & 83,33 & 81,67 & 73,33 & 78,33 & 71,67 & 82,86 & 76,19 \\
\hline & Index & A & A & A & A & A & A & A & A & A \\
\hline \multirow[t]{4}{*}{18} & DI & 1,50 & 1,50 & 2,17 & 1,33 & 1,67 & 1,50 & 2,00 & 1,43 & 1,90 \\
\hline & (rating) & A & A & A & A & A & A & A & B & A \\
\hline & Condition & 78,33 & 80,00 & 65,00 & 81,67 & 75,00 & 78,33 & 66,67 & 81,43 & 68,57 \\
\hline & Index & A & A & A & A & A & A & A & A & A \\
\hline
\end{tabular}

ES: Eucalyptus saligna; Eg: Eucalyptus grandis; Eu: Eucalyptus urophylla; Ep: Eucalyptus pellita; Ec: Eucalyptus camaldulensis; Cc: Corymbia citriodora; Er: Eucalyptus robusta; Hw: Heartwood; Tw: transition wood.

Means followed by the same capital letter in the lines of species and positions in each local do not differ (Scott-Knott; $p \leq 0,05$ ).

This is probably related to the presence of sapwood in this position, which contributes to higher moisture contents in the wood due to its higher permeability, in addition to the chemical compounds that can be leached, thus contributing to the attack from xylophagous agents (Brischke and Meyer-Veltrup 2015).

This natural similarity was probably created for resist the weathering and attack of xylophagous agents with respect to the evaluation time in the field, which occurred over one year and six months. According to Silva and Castro (2014), eucalypts wood has a useful life of between three and four years in the construction of fences, fencepost or stakes without preservative treatment. Thus, the variations in the natural durability among the species studied will be more important in the course of the next months. The same tendency in wear 
can be observed for the evaluated eucalypts wood previously exhibited for the soil bed test, which represent a similarity between the two performed tests.

A statistical difference was observed between the two positions evaluated after 12 and 18 months in the municipality of São José do Calçado, in which the transition region exhibited the highest wear values, being more susceptible to edaphoclimatic and biological factors (Table 4). This is probably related to the presence of sapwood in this position, which contributes to higher moisture contents in the wood due to its higher permeability, in addition to the chemical compounds which can be leached, thus contributing to the attack from xylophagous agents (Brischke and Meyer-Veltrup 2015).

There was a disparity between the middle heartwood and the transition region after 18 months of evaluation, and no statistically significant difference was observed among the tested woods. In general, the $E$. grandis and $E$. robusta species exhibited greater decay index, and the $C$. citriodora and $E$. pellita woods showed the lowest values during the three evaluations.

In the field decay test conducted in the city of Vargem Alta, it was noticed that there was a statistical difference between the two positions evaluated only in the third evaluation (18 months), with lower decay index and higher behavioral scores for the median heartwood (Table 4). This is related to the longer exposure time of the material to the edaphoclimatic and biological conditions of the region.

The evaluated species were statistically similar. This result is probably because they come from the same genus, with the exception of $C$. citriodora, and thus exhibit similar characteristics of natural durability in relation to the weathering and the biodeterioration caused by the xylophagous agents. Among these, the E. grandis, E. urophylla and E. robusta woods showed increased wear throughout the evaluations.

One of the main factors that probably influenced greater deterioration in São José do Calçado among the three evaluated municipalities is related to the organic matter content in the soil, especially in the B horizon with a value of $8,80 \%$, notably superior when compared to the content present in the municipality of Jerônimo Monteiro (3,60\%) and Vargem Alta (4,00\%).This favors the greater availability of nutrients in the soil, which provides favorable conditions for the development of xylophagous agents (Corassa et al. 2013, Carvalho et al. 2016).

The importance of moisture content is related to fungi and termites, in which fungi generally do not attack wood with moisture contents below $20 \%$, and precipitation enables water storage in the soil, which increases the risk of biodeterioration of material (Melo et al. 2010, Tomazeli et al. 2016). This culminated with higher deterioration values of the wood evaluated in São José do Calçado, which exhibited higher rainfall rates during the experiment.

Regarding temperature, this affects the metabolic activities of fungi such as digestion, assimilation, respiration, translocation, and syntheses performed by enzymes. The rates of metabolic reactions increase with increasing temperature, to the extent that any reaction becomes limiting at this speed, or the heat causes denaturation of the enzymes, being the ideal temperature for the development of (for example) fungi at around 22 ${ }^{\circ} \mathrm{C}$ to $36{ }^{\circ} \mathrm{C}$ (Li et al. 2013, Bouslimi et al. 2014).

The effect of temperature was verified with lower wear values for the wood from the test installed in Vargem Alta, which exhibited lower average temperatures than the other locations. In general, it was observed that the municipality of São José do Calçado presented the most favorable conditions for the natural deterioration of the wood (temperature and humidity), which resulted in higher wear values, as can be seen in Table 5 .

Table 5: Average decay index rating as a function of exposure time and position on the trunk for the three municipalities where the decay field tests were installed.

\begin{tabular}{|c|c|c|c|c|c|c|}
\hline \multirow{2}{*}{ Local } & \multicolumn{5}{|c|}{ Exposure time (months) } \\
\cline { 2 - 7 } & \multicolumn{2}{|c|}{$\mathbf{0 6}$} & \multicolumn{2}{c|}{12} & \multicolumn{2}{c|}{18} \\
\cline { 2 - 7 } & \multicolumn{2}{|c|}{ Decay index (rating) } & \multicolumn{2}{c|}{ Decay index (rating) } & \multicolumn{2}{c|}{ Decay index (rating) } \\
\cline { 2 - 7 } & Heartwood & Transition & Heartwood & Transition & Heartwood & Transition \\
\hline JM & $0,09 \mathrm{~B}$ & $0,24 \mathrm{~B}$ & $1,19 \mathrm{~B}$ & $1,38 \mathrm{~B}$ & $1,28 \mathrm{~B}$ & $1,43 \mathrm{~B}$ \\
\hline SJC & $1,24 \mathrm{~A}$ & $1,52 \mathrm{~A}$ & $2,33 \mathrm{~A}$ & $2,81 \mathrm{~A}$ & $2,48 \mathrm{~A}$ & $3,00 \mathrm{~A}$ \\
\hline VA & $0,00 \mathrm{~B}$ & $0,00 \mathrm{~B}$ & $1,33 \mathrm{~B}$ & $1,57 \mathrm{~B}$ & $1,43 \mathrm{~B}$ & $1,90 \mathrm{~B}$ \\
\hline
\end{tabular}


As observed, the edaphoclimatic influence must be especially evident in relation to the moisture content of the wood and the temperature of the environment. However, several other factors may influence the deterioration during the field test such as competition and antagonism among xylophagous agents, chemical composition and permeability of wood, distance between sources of infection, organic matter content and soil physical and chemical properties, which potentially retard or intensify the biodeterioration of wood (Brischke and Meyer-Veltrup 2016).

The soil of São José do Calçado soil yielded a lower $\mathrm{pH}$ value on average. In general, wood decaying fungi develop under more acidic conditions; $\mathrm{pH}$ with intervals between 3 and 6 (Brischke et al. 2013b), which favored a greater fungal attack in the woods installed in this municipality, in addition to the presence of termites.

According to Nicholas and Crawford (2003), the main soil nutrients required for fungi are nitrogen, phosphorus, potassium, magnesium and calcium. Thus, it can be observed that the soil in the municipality of Vargem Alta exhibited a lower average index, practically in all these chemical elements, and consequently resulted in the least decay index for the woods among the three evaluated municipalities. Thus, the natural durability of wood in soil-contact tests is influenced by a number of edaphoclimatic or biological factors that occur in isolation or the combination of both (Brischke et al. 2014).

It was generally observed that the decay indices obtained in the accelerated field and field simulator tests were very similar among the evaluated eucalypts wood. This validates the reduction of the evaluation time, and consequently of costs, when field simulators are used. Similar results were obtained by Nicholas and Crawford (2003) when assessing the durability of wood between these two biological tests.

\section{CONCLUSIONS}

For the soil bed test, the transition region of the stem showed the highest mass losses, regardless of soil origin and evaluated wood and in field decay test no statistical difference was observed between eucalypts wood to mass loss.

For the soil bed test, in general, the lowest mass losses of were observed for the Vargem Alta soil, except for Corymbia Citriodora and the greatest mass losses were observed for the Jerônimo Monteiro soil, except for Eucalyptus saligna and in field decay test the organisms present in the soil of São José do Calçado and related to the organic matter content Eucalyptus grandis and Eucalyptus saligna more intensely.

\section{ACKNOWLEDGEMENTS}

We thank the Foundation for Supporting Research and Innovation - FAPES, for the Doctorate Science scholarship to the first author, and to the Forestal Company Cellulose Nipo Brasileira - CENIBRA S.A for making the research material available.

\section{REFERENCES}

Ali, A.C.; Uetimane, E.; Råberg, U.; Terziev, N. 2011. Comparative natural durability of five wood species from Mozambique. Int Biodeter Biodegr 65(6): 768-776. https://doi.org/10.1016/j.ibiod.2011.03.010

AWPA. 2014. Standard method of evaluating wood preservatives in a soil bed. E14-14. AWPA Birmingham, AL, USA. 668p.

Araújo, J.B.S.; Paes, J.B. 2018. Natural wood resistance of Mimosa caesalpiniifolia in field testing. Floram 25(2): 1-6. https://doi.org/10.1590/2179-8087.012815 
Becker, G. 1972. Suggested standard method for field tests with wooden stakes. PANS Pest Articles \& News Summaries 18(1): 137-142. https://doi.org/10.1080/09670877209413483

Bouslimi, B.; Koubaa, A.; Bergeron, Y. 2014. Effects of biodegradation by brown-rot decay on selected wood properties in eastern white cedar (Thuja occidentalis L.). Int Biodeter Biodegr 87: 87-98. https://doi.org/10.1016/j.ibiod.2013.11.006

Brischke, C.; Meyer, L.; Alfredsen, G.; Humar, M.; Francis, L.; Flaete, P.O.; Larsson-Brelid, P. 2013a. Natural durability of timber exposed above ground - a survey. Drvna Ind 64(2): 113-129. https://doi.org/10.5552/drind.2013.1221

Brischke, C.; Olberding, S.; Meyer, L.; Bornemann, T.; Welzbacher, C.R. 2013b. Intrasite variability of fungal decay on wood exposed in ground contact. International Wood Products Journal 4(1): 37-45. https://doi.org/10.1179/2042645312Y.0000000014

Brischke, C.; Meyer, L.; Olberding, S. 2014. Durability of wood exposed in ground e comparative field trials with different soil substrates. Int Biodeter Biodegr 86(Part B): 108-114. https://doi.org/10.1016/j.ibiod.2013.06.022

Brischke, C.; Meyer-Veltrup, L. 2016. Modelling timber decay caused by brown rot fungi. Mater Struct 49(8): 3281-3291. https://doi.org/10.1617/s11527-015-0719-y

Brischke, C.; Meyer-Veltrup, L. 2015. Moisture content and decay of differently sized wooden components during 5 years of outdoor exposure. Eur J Wood Wood Prod 73(6): 719-728. https://doi.org/10.1007/s00107-015-0960-7

Carvalho, D.E.; Martins, A.P.M.; Santini, E.J.; Freitas, L.S.; Talgatti, M.; Susin, F. 2016. Natural durability of Eucalyptus dunnii Maiden, Eucalyptus robusta Sm. Eucalyptus tereticornis Sm. and Hovenia dulcis Thunb. wood in field and forest environment. Rev Arvore 40(2): 363-370. https://doi.org/10.1590/0100-67622016000200019

Corassa, J.N.; Castelo, P.A.R.; Stangerlin, D.M.; Magistrali, I.C. 2013. Durabilidade natural da madeira de quatro espécies florestais em ensaios de deterioração em campo. Revista Ciência da Madeira 4(1): 108-117. https://periodicos.ufpel.edu.br/ojs2/index.php/cienciadamadeira/article/view/4050

IBÁ. 2019. Ano Base: 2018. São Paulo, Brazil. 80p. https://www.iba.org/publicacoes/relatorios

Li, Q.; Lin, J.G.; Liu, J. 2013. Decay resistance of wood treated with extracts of Cinnamomum camphora xylem. BioResources 8 (3): 4208-4217. https://doi.org/10.15376/biores.8.3.4208-4217

Melo, R.R.; Stangerlin, D.M.; Santini, E.J.; Haselein, C.R.; Gatto, D.A.; Susin, F. 2010. Durabilidade natural da madeira de três espécies florestais em ensaios de campo. Cienc Florest 20(2): 357-365. http://dx.doi.org/10.5902/198050981858.

Meyer, L.; Brischke, C.; Melcher, E.; Brandt, K.; Lenz, M.T.; Soetbeer, A. 2014. Durability of english oak (Quercus robur L.) e comparison of decay progress and resistance under various laboratory and field conditions. Int Biodeter Biodegr 86(Part B): 79-85. https://doi.org/10.1016/j.ibiod.2013.06.025.

Morais, F.M.; Costa, A. F. 2007. Alteração da cor aparente de madeiras submetidas ao ataque de fungos apodrecedores. Revista Brasileira de Ciências Agrárias 2(1): 44-50. https://www.redalyc.org/pdf/1190/119017336008.pdf

Nicholas, D.D.; Crawford, D. 2003. Concepts in the development of new accelerated test methods for wood decay. In: Wood deterioration and preservation: advances in our changing world. Goodell, B.; Nicholas, D. D; Schultz, T. P. (Eds.). American Chemical Society: Washington, DC, USA. 463p. ISBN 0-8412-3797-2.

Paes, J.B.; Vital, B.R.; Della Lucia, R.M.; Della Lucia, T.M.C. 2002. Effects of the purification and enrichment of wood tar creosote on preservation of Eucalyptus grandis wood, after 48 months of field testing. Rev Arvore 26(4): 475-484. https://doi.org/10.1590/S0100-67622002000400010

Paes, J.B.; Melo, R.R.; Lima, C.R.; Oliveira, E. 2007. Resistência natural de sete madeiras ao cupim 
subterrâneo (Nasutitermes corniger Motsch.) em ensaio de preferência alimentar. Revista Brasileira de Ciências Agrárias 2(1): 57-62. http://www.agraria.pro.br/ojs-2.4.6/index.php?journal=agraria\&page=article\&op=view\&path $\% 5 \mathrm{~B} \% 5 \mathrm{D}=1885$

Paes, J.B.; Morais, V.M.; Lima, C.R.; Santos, G.J.C. 2009. Natural resistance of nine woods from the Brazilian semiarid region to wood-destroying fungi in field simulators. Rev Arvore 33(3): 511-520. https://doi.org/10.1590/S0100-67622009000300013.

Paes, J.B.; Souza, A.D.; Lima, C.R.; Souza, P.F. 2012. Efficiency of neem (Azadirachta indica A. Juss.) and castor oil plant (Ricinus communis L.) oils for the improvement of Ceiba pentranda (L.) Gaerth. wood resistance to xilophagous fungi in soil bed test. Cienc Florest 22(3): 617-624. https://doi.org/10.5902/198050986627

Paes, J.B.; Brocco, V.F.; Moulin, J.C.; Motta, J.P.; Alves, R.C. 2015. Effects of extractives and density on natural resistance of woods to termite Nasutitermes corniger. Cerne 21(4): 569-578. https://doi.org/10.1590/01047760201521041849

Shmulsky, R.; Jones, P.D. 2011. Forest products and wood science: an introduction. 6 ed.Wiley-Blackwell: Oxford, UK. 483p. ISBN-13: 978-0-8138-2074-3.

Silva, J.C.; Caballeira Lopez, A.G.; Oliveira, J.T.S. 2004. Influência da idade na resistência natural da madeira de Eucalyptus grandis W. Hill ex. Maiden ao ataque de cupim de madeira seca (Cryptotermes brevis). Rev Arvore 28(4): 583-587. https://doi.org/10.1590/S0100-67622004000400012

Silva, J.C.; Castro, V.R. 2014. Propriedades e usos da madeira de eucalipto. Editora Arbotec: Viçosa, Brazil. 67p. ISBN: 9788581790657.

Steel, R.G.D.; Torrie, J.H. 1980. Principles and Procedures of Statistic: a Biometrical Approach. 2 ed. McGraw Hill: New York, USA. 633p.

Sundararaj, R.; Shanbhag, R.R.; Nagaven, H.C.; Vijayalakshmi, G. 2015. Natural durability of timbers under Indian environmental conditions-an overview. Int Biodeter Biodegr 103: 196-214. https://doi.org/10.1016/j.ibiod.2015.04.026.

Susi, P.; Aktuganov, G.; Himanen, J.; Korpela, T. 2011. Biological control of wood decay against fungal infection. J Environ Manage 92(7): 1681-1689. https://doi.org/10.1016/j.jenvman.2011.03.004

Tomazeli, A.J.; Silveira, A.G.; Trevisan, R.; Wastowski, A.D.; Cardoso, G.V. 2016. Durabilidade natural de quatro espécies florestais em campo de apodrecimento. Tecno-lógica 20(1): 20-25. https://doi.org/10.17058/tecnolog.v20i1.6473.

Vinden, P.; Savory, J.G.; Dickinson, D.J.; Levy, J.F. 1982. Soil-bed studies. In Proceedings IRG Annual Meeting, IRG/WP/2181. The International Research Group on Wood Protection: Stockholm, Sweden, 15p. 